\title{
Upaya Peneguhan Eksistensi Lembaga Amil Zakat Sebagai Salah Satu Bentuk Faith Based Organization di Indonesia.
}

\author{
Sari Viciawati Machdum
}

\begin{abstract}
Zakah in Indonesia has a great potential in contributing the improvement of life quality of people in need in Indonesia. With this such potential, many Amil Zakah Institutions (Lembaga Amil Zakat/LAZ) are founded in Indonesia as faith based organizations (FBO). The literatures mentioned that Faith Based Organization has already taken its own place in the world of Social Work and Social Welfare. This article discussed the LAZ existence as one of the FBO in Indonesia. Utilization of zakah from charity to empowerment-including economic empowerment-has been an evidence that $L A Z$ evolved into a better direction. This certainly can negate the negative stigma that has been pinned to social services of the FBO.
\end{abstract}

Key words: faith based organization, human service organization, manajemen, lembaga amil zakat

\section{Pendahuluan}

Zakat adalah salah satu potensi yang perlu didayagunakan secara maksimal karena memiliki kebermanfaatan yang bisa dipergunakan untuk meminimalisir jumlah kaum dhuafa di Indonesia. Sebagaimana yang dikemukakan oleh Bachty (1998 : 204) mengenai kelebihan dari proses penyaluran zakat yang dikelola oleh lembaga resmi seperti Badan Usaha Mandiri Terpadu atau Baitul Mal Wat Tamwil. Dimana lembaga ekonomi tersebut lebih bisa menjangkau rakyat kelas bawah yang tentu saja tidak berkemampuan untuk meminta bantuan dari bank dengan berbagai persyaratan yang ada.

Di sisi lain, jumlah penduduk muslim di Indonesia juga sangat banyak dan bahkan mendominasi seluruh jumlah penduduk di Indonesia. Bahkan pada saat ini pun angka zakat yang telah terkumpulkan menungjukkan angka yang fantastis. Hal ini bisa dilihat dalam bagan berikut ini:

Tabel 1.

\section{Pengumpulan Dana ZISWAF Nasional}

\begin{tabular}{|c|c|c|c|c|c|c|}
\hline \multirow{2}{*}{$\begin{array}{c}\text { Nama } \\
\text { Lembaga }\end{array}$} & \multicolumn{6}{|c|}{ Penerimaan ZISWAF (Ribuan Rupiah) } \\
\hline & 2002 & 2003 & 2004 & 2005 & 2006 & 2007 \\
\hline BAZNAS & 921,048 & $2,700,073$ & $3,322,092$ & $31,406,810$ & $28,316,016$ & $26,900,629$ \\
\hline $\begin{array}{c}\text { BAZDA } \\
\text { (Provinsi) }\end{array}$ & $11,589,000$ & $14,177,504$ & $18,412,132$ & $30,301,714$ & $114,406,553$ & $102,629,312$ \\
\hline LAZ & $55,680,209$ & $68,405,946$ & $128,354,888$ & $233,986,019$ & $230,613,161$ & $219,412,453$ \\
\hline TOTAL & $68,190,257$ & $85,283,523$ & $150,089,112$ & $295,694,543$ & $373,335,730$ & $384,942,394$ \\
\hline
\end{tabular}

Sumber: Laporan Tahunan Baznas (dalam Wibisono, 2009 : 31) 
Berdasarkan tabel 1. dapat dilihat bahwa ada begitu jumlah dana yang bisa dikelola untuk memperbaiki kondisi masyarakat Indonesia yang belum beruntung. Mengenai hal tersebut, Beik (2009 : 54) melalui penelitiannya juga telah membuktikan bahwa zakat memang mampu mengurangi kemiskinan dengan mengurangi jumlah keluarga miskin dari $84 \%$ menjadi 74\%. Siena (2005 : 90) juga menyatakan bahwa "dana ZIS yang disalurkan kepada mustahiq berpengaruh positif terhadap peningkatan pendapatan usaha".

Di sisi lain, pendayagunaan dana zakat di Indonesia juga belum bisa optimal secara maksimal. Pikiran Rakyat (Amaliya, Prasetya, D., Handriansyah, H., Marlia, L., 2009) menuliskan hasil survei Public Interest Research and Advocacy Center (PIRAC) di sepuluh kota besar di Indonesia pada akhir 2007 yang menyatakan bahwa dengan populasi Muslim sebanyak $87 \%$ dari total jumlah penduduk, potensi zakat Indonesia pada 2007 mencapai Rp 9,09 triliun atau sekitar 1,5 kali jumlah APBD Jabar 2008. Namun sangat disayangkan, potensi besar itu berbanding terbalik dengan tingkat kesadaran muzaki terhadap kewajiban membayar zakat yang hanya sekitar 55\%. Selain tingkat kesadaran yang rendah, faktor performa dari LAZ di Indonesia juga turut andil dalam meningkatkan rasa percaya (trust) masyarakat untuk menyalurkan zakatnya melalui LAZ. (Republika News Room, 2009).

Mengenai pendayagunaan dana zakat di Indonesia, Saidi (2004 : 93) mengungkapkan:

"Jumlah ziswaf tahunan yang dikeluarkan oleh umat Islam di Indonesia relatif besar, diperkirakan di atas Rp 5 triliun. Tanpa LAZIS umat islam umumnya menyerahkan dana ZIS-nya langsung kepada penerima, yakni handai taulan, fakir miskin, yatim piatu, orang tua jompo, dan sejenisnya. Maka uang triliyunan itu akan terkumpul, terbagikan dan habis terpakai, untuk konsumsi hari ini. Alih-alih mengentaskannya, pembagian zis tetap melestarikan kemiskinan. Pengelolaan ZIS tradisional bahkan menimbulkan ekses negatif, sampai memakan korban para pencari sedekah..."

Pemaparan Saidi mengenai fenomena dunia zakat di Indonesia merupakan suatu hal yang menyedihkan. Padahal dana zakat akan jauh lebih bermanfaat apabila dikelola oleh lembaga yang profesional. Apalagi Gusfahmi (2009 : 36-37) mengatakan kehadiran zakat dalam agama Islam memang ditujukan untuk mengentaskan kemiskinan. Bahkan Mintarti, Kurniadi dan Utomo (2009 : 19) menyebutkan bahwasanya ada sebuah tuntutan terhadap pengelola zakat untuk bisa melakukan perubahan kepada para penerima zakat (mustahik). Salah satu tujuan juga besar, yaitu merubah mustahik menjadi muzakki. Hal ini memperlihatkan bahwa amanah LAZ pada hakikatnya tidak sederhana. Jadi pendayagunaan zakat yang bersifat charity seyogyanya perlu dirubah dan diarahkan kepada kegiatan yang bersifat pemberdayaan. Dengan demikian adanya zakat bisa lebih bermakna dalam perubahan kualitas hidup masyarakat yang membutuhkan.

Artikel ini memberikan paparan mengenai bagaimana LAZ memberikan kontribusinya dalam mendayagunakan dana zakat. Dalam perkembangannya, dana zakat yang dialokasikan oleh LAZ tidak hanya terkait dengan kegiatan charity saja. Wibisana (2004 : 124-146) menyebutkan bahwa kegiatan pendayagunaan zakat telah beragam, antara lain sosialisasi dan edukasi zakat, bantuan da'wah (benah madrasah dan masjid), kegiatan kemanusiaan (pemberian bantuan kepada para korban bencana), dan bantuan di bidang kesehatan. Selain itu, ada pula kegiatan pemberdayaan seperti pemberdayaan ekonomi yang perkembangannya 
juga menarik. Perkembangan tersebut pun diikuti oleh berbagai penelitian yang datang dari berbagai disiplin ilmu. Studi literatur ini menggambarkan bagaimana perkembangan eksistensi FBO itu sendiri. Terutama perkembangan FBO di Indonesia dimana LAZ sebagai salah satu bentuknya dijadikan sebagai salah satu contoh.

\section{Pembahasan}

Zakat sebagai salah satu potensi pembangunan di Indonesia memang besar. Apalagi dana zakat yang terhimpun di Indonesia, sebagaimana yang tergambarkan dalam Tabel 1 , semakin meningkat di setiap tahunnya. Menurut sebuah riset yang dilakukan oleh Tasniawan (2008 : 65) yang melakukan penelitian di BAZNAS, keberadaan Undang-undang no. 38 Tahun 1999 menjadi salah satu hal yang mempengaruhi tingkat kepercayaan wajib zakat. Namun bila dilihat dari jumlah keseluruhannya, angka dana zakat yang terhimpun di LAZ jauh lebih menonjol dalam menghimpun dana zakat jika dibandingkan dengan organisasi pengelola zakat lainnya.

Belum diketahui apa yang menyebabkan LAZ menghimpun dana zakat yang jauh lebih besar dari pada OPZ yang diselenggarakan oleh pemerintah. Namun issu mengenai dunia lembaga perzakatan dan reaksi masyarakat terhadapnya juga tidak terhenti pada permasalahan rasa percaya muzakki dan transparansi pendayagunaan zakat dan manajemennya. Belakangan ini muncul pula wacana mengenai urgensi pengelolaan zakat yang terpusat pada lembaga pemerintah. Gagasan ini muncul berdasarkan apa yang dilakukan umat muslim pada masa nabi dan Khulafaur Rasyidin. (Pemimpin setelah Nabi Muhammad SAW). Dimana pemerintah pada masa itu memiliki kewenangan dalam pengurusan zakat (Fuaida, 2005 : 267). Apalagi bila dibandingkan dengan negara tetangga seperti Malaysia dan Singapura, Fatahillah (2003 : 70) juga menuliskan "Indonesia masih tertinggal jauh dalam pengelolaan ZIS karena di dua negara tersebut telah lama membentuk Undang-undang Pengelola Zakat (UUPZ) dimana pengumpulan ZIS dilakukan secara terpusat (oleh pemerintah)". Pengelolaan yang terpusat seperti itu dinilai hingga dana ZIS berjumlah besar, terencana dan terkoordinasi.

Ada banyak kalangan yang menolak wacana terpusatnya pengelolaan dana zakat. Suharto (2009 : 9-10) menjelaskan zakat dalam sejarah Islam memang tidak pernah berjalan dengan sempurna. Pada awalnya, pemerintahlah yang memegang kewenangan dalam perihal pengelolaan zakat. Namun dalam prosesnya selanjutnya, ada pula masa dimana umat Islam tidak memiliki rasa percaya pada penguasa. Hal ini terjadi terutama ketika Ustman terbunuh. Lalu pada periode khalifah ke-4: Ali bin Abi Thalib. Keadaan semakin buruk. Namun sejatinya, zakat tetap berjalan secara ritual.

Terkait dengan kondisi Indonesia, ketidaksepakatan mengenai sistem pengelolaan zakat — apakah terpusat atau tidak — tentu tidak perlu menghalangi arti dasar dari ritual zakat itu sendiri yang sejatinya ingin membangun kesejahteraan umat dengan meminimalisir adanya ketidakadilan sosial. Apalagi muzakki juga harus menghadapi issu lain: umat islam memiliki dua beban pengeluaran berupa kewajiban membayar zakat dan juga pajak. Mengenai hal ini, Sirmu (2007 : 147) menuliskan bahwa "dalam perjalanan hukum Islam, pajak juga dikenal.” Dengan demikian beban ganda yang ada pada para muzakki memang tidak dapat dihindari. Namun perlu digarisbawahi dalam penelitian yang dilakukan Sirmu 
(2007 : 147) adalah "pajak yang dikenal pada masa Rasulullah berbeda dengan yang ada pada konsep kapitalis pada saat ini." Gusfahmi (2009 : 38-39) merincikan apa saja yang menyebabkan pembayaran pajak, khususnya di Indonesia menjadi beban tersendiri pada diri muzakki. Ia menuliskan, selain belum ada fatwa MUI, Indonesia juga memiliki jenis pajak yang terlalu banyak. Sebut saja PPh, PPN, PBB, BPHTB. Selain itu, pemeritah juga masih memungut 11 jenis pajak lainnya. Bahkan World Bank melakukan survey dan menemukan ada 52 jenis pajak yang dipungut di Indonesia. Berarti beban finansial yang ada pada para muzakki memang berlipat-lipat.

Kebijakan zakat sebagai faktor pengurang pajak dalam UU PPh dan UU Zakat sangat membantu umat Islam. Apalagi kepercayaan masyarakat Indonesia yang selama ini membayar pajak semakin menurun mengingat penilaian masyarakat yang negatif terhadap kemampuan pajak dalam mengentaskan kemiskinan (Yarmanto, 2003 : 143). Belum lagi paparan berbagai berita mengenai korupsi dana pajak yang sangat mencengangkan.

Di sisi lain, pendayagunaan dana zakat di Indonesia juga belum bisa optimal secara maksimal. Pikiran Rakyat (Amaliya, Prasetya, D., Handriansyah, H., Marlia, L., 2009) menuliskan hasil survei Public Interest Research and Advocacy Center (PIRAC) di sepuluh kota besar di Indonesia pada akhir 2007 yang menyatakan bahwa dengan populasi Muslim sebanyak $87 \%$ dari total jumlah penduduk, potensi zakat Indonesia pada 2007 mencapai Rp 9,09 triliun atau sekitar 1,5 kali jumlah APBD Jabar 2008. Namun sangat disayangkan, potensi besar itu berbanding terbalik dengan tingkat kesadaran muzaki terhadap kewajiban membayar zakat yang hanya sekitar 55\%. Selain tingkat kesadaran yang rendah, faktor performa dari LAZ di Indonesia juga turut andil dalam meningkatkan rasa percaya (trust) masyarakat untuk menyalurkan zakatnya melalui LAZ. (Republika News Room, 2009).

Mengenai pendayagunaan dana zakat di Indonesia, Saidi (2004 : 93) mengungkapkan:

"Jumlah ziswaf tahunan yang dikeluarkan oleh umat islam di Indonesia relatif besar, diperkirakan di atas Rp 5 triliyun. Tanpa LAZIS umat islam umumnya menyerahkan dana zis-nya langsung kepada penerima, yakni handai taulan, fakir miskin, yatim piatu, orang tua jompo, dan sejenisnya. Maka uang triliunan itu akan terkumpul, terbagikan dan habis terpakai, untuk konsumsi hari ini. Alih-alih mengentaskannya, pembagian zis tetap melestarikan kemiskinan. Pengelolaan zis tradisional bahkan menimbulkan ekses negatif, sampai memakan korban para pencari sedekah..."

Pemaparan Saidi mengenai fenomena dunia zakat di Indonesia merupakan suatu hal yang menyedihkan. Padahal dana zakat akan jauh lebih bermanfaat apabila dikelola oleh lembaga yang profesional. Apalagi Gusfahmi (2009 : 36-37) mengatakan kehadiran zakat dalam agama Islam memang ditujukan untuk mengentaskan kemiskinan. Bahkan Mintarti, Kurniadi dan Utomo (2009 : 19) menyebutkan bahwasanya ada sebuah tuntutan terhadap pengelola zakat untuk bisa melakukan perubahan kepada para penerima zakat (mustahik). Salah satu tujuan juga besar, yaitu merubah mustahik menjadi muzakki. Sedangkan pendayagunaan dana zakat yang efisien berarti pendistribusian dana zakat ke masyarakat berdasarkan manajemen yang profesional.

Pendayagunaan dana zakat yang terbukti bisa dijalankan dengan manajemen yang profesional diharapkan dapat meningkatkan rasa percaya muzakki terhadap Organisasi 
Pengelola Zakat, salah satunya adalah LAZ. Namun sangat disayangkan sebagaimana yang disampaikan oleh Fatahillah (2003 : 69), penduduk muslim di DKI Jakarta, yang artinya berada di suatu wilayah dengan akses informasi yang baik, ternyata memiliki kesadaran yang rendah dalam berzakat. Kalaupun sebagian muslim telah menjalankan salah satu kewajibannya ini secara rutin, ternyata mereka lebih memilih untuk memberikan sebagian hartanya secara langsung kepada yang berhak. Alasan perilaku muzakki tersebut ada pada sebuah hasil penelitian yang dilakukan oleh Subekti (2003 : 93) yang menuliskan:

"Mekanisme tradisional sejauh ini masih dianggap yang paling efektif dijalankan warga. Karena mekanisme lain, seperti membayarkan zakat melalui badan dan lembaga zakat belum bisa memberikan kepastian bahwa zakatnya akan sampai ke tangan orang-orang yang berhak. Kekhawatiran akan terjadi penyelewengan menjadikan warga memilih mengelola zakatnya sendiri."

Palmawati (1997 : 138) dalam penelitiannya juga mengemukakan beberapa kendalakendala para muzakki (wajib zakat) sehingga tidak menyerahkan zakatnya kepada organisasi pengelola zakat, yakni:

1. Karena Pengelola zakat belum berfungsi sebagaimana mestinya.

2. Karena muzakki (wajib zakat) kurang percaya terhadap pengelola zakat.

3. Karena muzakki (wajib zakat) belum mengetahui keberadaan pengelola zakat.

4. Karena sudah menjadi kebiasaan muzakki (wajib zakat) menyerahkan langsung zakatnya kepada yang berhak menerimanya, dan

5. Karena ketidaktahuan muzakki (wajib zakat) menghitung zakatnya.

Berbagai kendala tersebut adalah suatu hal yang merugikan mengingat potensi zakat yang bergitu besar untuk membangun bangsa ini. Hal ini perlu dijadikan sebagai pengingatan pada berbagai organisasi pengelola zakat. Apalagi LAZ yang selama ini mampu menghimpun dana zakat terbanyak (lihat tabel 1.1.) dalam memperbaiki performanya sebagai salah satu OPZ.

Namun seiring dengan waktu, perkembangan dunia zakat di Indonesia mengalami perkembangan yang pesat. Berbagai OPZ termasuk LAZ banyak yang telah berbenah diri. Berdasarkan penelitian, beberapa lembaga amil zakat seperti Lembaga Amil Zakat Dompet Dhuafa, Lembaga Pembangunan Ummat dan Amil Zakat Nasional Pos Keadilan Peduli Umat, Dana Sosial Ummul Qura, Yayasan Dana Sosial Al-Falah, Dompet Peduli Umat Darut Tauhid, memiliki semangat yang kuat dalam menjalankan prinsip-prinsip good governance yang sangat penting dalam meningkatkan rasa percaya muzakki terhadap LAZ. Semangat yang dimaksudkan bisa terlihat dari beberapa kegiatan LAZ yang terdiri dari (Wibisana, 2004 : 109-115):

1. Memberikan informasi secara periodik tentang hal-hal yang menyangkut pengelolaan zakat kepada pembayar zakat.

2. Memberikan hak kepada para pembayar zakat untuk meminta informasi tentang pengelolaan dana zakat.

3. LAZ juga melakukan pertanggungjawaban dan akuntabilitasnya kepada pengurus yayasan sebagai atasan amil zakat. 
Kegiatan LAZ yang dijadikan sebagai objek penelitian pada nomer 1, memberikan informasi secara periodik tentang hal-hal yang menyangkut pengelolaan zakat kepada pembayar zakat, dapat menutupi tanggapan Wibisana (2004 : 8) mengenai UU Nomor 38 tahun 1999 tentang Pengelolaan Zakat, yang melihat adanya kekurangan UU tersebut. Kekurangannya yakni pada ketidakmampuan UU tersebut dalam memberikan pengakuan legal terhadap keberadaan hukum lembaga amil zakat di Indonesia. Hal ini berarti posisi LAZ sebagai OPZ tidak dikenal dalam sistem hukum di Indonesia. Posisi muzakki yang sebenarnya menjadi salah satu stakeholder utama LAZ juga tidak memiliki perlindungan hukum. Hubungan hukum yang terjadi antara muzakki dan LAZ hanya pada saat pembayaran zakat. Padahal dana yang dikelola oleh LAZ mutlak hanya dana titipan. Hal ini berarti ada tanggung jawab sangat besar yang diemban LAZ untuk mengkomunikasikan proses pengelolaan dana yang diterimanya kepada muzakki.

Laporan yang disampaikan LAZ kepada muzakki mengenai proses pendayagunaan zakat kini telah banyak dilakukan. Bahkan ada pula LAZ yang menyampaikannya secara online melalui media internet. Biasanya laporan pendayagunaan yang disampaikannya seputar pada bagaimana LAZ tersebut menyampaikan dana zakat kepada yang berhak dengan ragam alokasinya, antara lain sebagaimana yang disebutkan Wibisana (2004 : 124146): sosialisasi dan edukasi zakat, bantuan dakwah (benah madrasah dan masjid), kegiatan kemanusiaan (pemberian bantuan kepada para korban bencana), dan bantuan di bidang kesehatan.

Upaya LAZ dalam memaparkan penggunaan dana zakat secara transparan kepada khalayak umum memang patut dihargai. Namun upaya ini tentu akan jauh lebih baik apabila LAZ juga memberikan pertanggungjawabannya secara detil mengenai upayanya dalam mencapai tujuan kegiatan pendistribusian zakat itu sendiri, yakni memberikan perubahan yang nyata kepada masyarakat.

Laporan rinci mengenai kegiatan pemberdayaan masyarakat yang dilakukan LAZ menjadi sangat penting. Salah satunya adalah untuk meningkatkan rasa percaya para muzakki yang menjadi salah satu stakeholder utama di LAZ. Jaelani (2008 : 113) dalam penelitiannya juga menunjukkan ada pengaruh yang signifikan dari variabel kualitas pelayanan keputusan muzakki untuk berzakat. Jadi LAZ perlu memberikan perhatian yang lebih pula dalam memberikan layanan kepada para muzakki.

Laporan yang terperinci mengenai bagaimana proses pendayagunaan dana zakat dilakukan secara tidak langsung tentu akan mendorong LAZ sebagai organisasi nirlaba membutuhkan berbagai gagasan yang inovatif dan kreatif. Sehingga LAZ lebih bisa mengupayakan adanya usaha kesejahteraan sosial yang tidak hanya sekedar produk salinan dari kegiatan pemberdayaan masyarkat yang telah dilakukan di organisasi atau daerah lain. Lebih dari itu, kegiatan usaha kesejahteraan sosial yang ada memang benar-benar berangkat dari permasalahan dan kebutuhan serta potensi masyarakat sebagai subjek pembangunan. Sehingga pendayagunaan dana zakat dapat memberikan makna yang nyata dalam proses perubahan masyarakat menuju kualitas hidup lebih baik. Sebagaimana yang dikemukakan oleh Khatimah (2004: 135). 
“...Model pemberdayaanumat tidakhanya dapat denganmemberikanzakat (mendistribusikan), tetapi perlu ditindaklanjuti dengan pembangunan secara ekonomi, sosial, dan keagamaan disertai dengan pengawasan dan evaluasi untuk meningkatkan dan mempercepat proses kemandirian mustahik." (Khatimah, 2004 : 135)

Dari apa yang disampaikan oleh Khatimah tersebut menekankan bahwa dana zakat seyogyanya tidak hanya disebarkan kepada yang berhak (mustahik). Lebih dari itu, zakat yang diberikan harus bisa memfasilitasi mustahik dalam merubah kondisi hidupnya. Caranya tentu tidak hanya dengan melakukan pemberdayaan di bidang ekonomi semata. Tetapi juga dengan melakukan pemberdayaan ekonomi yang bisa merambah berbagai aspek kehidupan mustahik, baik secara sosial maupun spiritual.

Namun pemberdayaan ekonomi yang seperti demikian pada praktiknya juga tidak sederhana. Lembaga pelayanan yang menyalurkan zakat sebagai organisasi pelayanan (human service organization) perlu memperhatikan berbagai aspek mengingat 'raw material' yang dikelolanya adalah manusia yang memiliki karakter beragam. Kendatipun upaya pemberdayaan ekonomi sudah begitu lekat dengan LAZ dan para front liner-nya juga sudah mengetahui konsep "community development", pengetahuan mengenai hal tersebut sering kali tidak memberikan bekal yang cukup bagi para pendamping dalam melaksanakan tugasnya.

Ada berbagai penelitian yang bisa dipergunakan sebagai acuan para pendamping dalam mencapai tujuannya. Salah satunya adalah penelitian yang pernah dilakukan oleh Mufraini (2003 : 132-133) yang melihat perilaku konsumtif dinilainya akan menjadi indikator pengganggu kesinambungan program distribusi Zakat. Oleh karenanya, sebagaimana penelitian yang dilakukan oleh Fuaida (2005 : 234-253), pendamping juga hatus memperhatikan faktor manajemen keuangan keluarga sebagai hal yang sangat penting dalam melaksanakan program pemberdayaan ekonomi.

Tidak hanya itu, ada hal lain pula yang perlu diperhatikan oleh pendamping. Antara lain seperti yang disampaikan oleh Kurnia (2009) yang menyebutkan faktor-faktor yang mempengaruhi lamanya waktu yang dibutuhkan mustahik untuk merubah pendapatan, antara lain:

a. jumlah dana zakat yang diberikan (pemberian dana zakat kurang dari dan sama dengan satu juta rupiah sama lebih cepat meningkatkan pendapatan mustahik dibandingkan dengan kelompok yang diberikan dana lebih dari satu juta rupiah)

b. lembaga pemberi bantuan dan

c. motivasi (mustahik memiliki motivasi yang tinggi)

Temuan Kurnia (2009) yang menyebutkan faktor motivasi sebagai suatu hal yang mempengaruhi lamanya waktu yang dibutuhkan mustahik untuk merubah pendapatan, menambah penekanan kembali pada urgensi peran pendamping yang juga dituntut untuk bisa merubah perilaku para mustahik. Penelitian tersebut juga menjadi penegasan kembali pada peran pendamping yang selama ini memang menjadi ujung tombak organisasi dalam merubah perilaku maupun kondisi kesejahteraan para mustahik.

Terkait dengan urgensi peran pendampingan tersebut, Dewi (2006 : 144-149) melakukan penelitian mengenai upaya pendampingan dalam proses pemberdayaan 
ekonomi yang dilakukan oleh salah satu LAZ terkemuka di dua desa, yakni di desa Muara dan Rancalabuh. Salah satu desa tersebut, yakni desa Muara, memperlihatkan hasil positif. Sedangkan desa Rancalabuh sebagai perbandingannya ternyata tidak memberikan hasil yang tidak diharapkan. Salah satu penyebab kegagalannya adalah karena kurang optimalnya proses pendampingan yang dilakukan di Desa Rancalabuh. Dalam penelitian tersebut dinyatakan bahwa pendamping telah melakukan upaya 'pemaksaan' dalam hal pemilihan jenis usaha yang akan dijalankan oleh para anggota komunitas sasaran.

Kesalahan pendamping dalam melakukan intervensi sosial memang dapat berakibat fatal. Namun pada prosesnya, pendamping sebagai salah satu elemen hidup yang tidak terpisahkan dari sub sistem lain di luar dirinya: organisasi yang mempekerjakan pendamping.

Sebelumnya juga telah disinggung mengenai temuan Kurnia (2009) yang menekankan urgensi lembaga sebagai salah satu faktor yang mampu mempengaruhi perilaku mustahik. Namun yang kemudian membuat hasil penelitian Dewi menjadi menarik adalah lembaga pelaksana intervensi sosial yang menjadi objek penelitiannya adalah sebuah LAZ yang dikenal dengan profesionalismenya. Hal ini memberikan gambaran bahwa LAZ yang dikenal memiliki manajemen yang baik tidak selamanya menjamin adanya pengembangan program intervensi sosial yang baik pula. Kesimpulan tersebut mengarah pada pertanyaan mendasar mengenai bagaimana seharusnya melakukan upaya pemberdayaan masyarakat sebagai salah satu usaha kesejahteraan sosial.

Mengenai pengembangan usaha kesejahteraan sosial yang dilakukan oleh LAZ, Adi (2002 : 28-58) memaparkan beberapa diskursus yang memperkaya ragam intervensi sosial. Diskursus tersebut dibedakan dalam beberapa kutub. Secara vertikal, ada kutub top down dan bottom up. Sedangkan secara horizontal, ada kutub positivistik dan humanistik. Kutub-kutub tersebut sekiranya dapat memberikan penjelasan bahwasanya intervensi sosial bisa kian beragam tergantung pada bagaimana kerangka berpikir pemegang kebijakan dan pelaku perubahan yang melakukan intervensi sosial. Kecenderungan mereka terhadap masing-masing kutub akan sangat mempengaruhi wujud intervensi sosialnya. Jika kerangka berpikirnya lebih berkiblat pada kutub top down-positivistik, maka intervensi sosialnya mengarah pada diskursus manajerial. Sedangkan bila kerangka berpikirnya lebih lebih berkiblat pada kutub top down-humanistik, maka intervensi sosialnya lebih diwarnai oleh dikursus profesional. Lalu bila kerangka berpikirnya lebih berkiblat pada kutub PositivistikBottom up, maka intervensi sosialnya mengikuti arus diskursus Pasar. Sedangkan bila kerangka berpikirnya lebih mengarah pada kutub bottom up-humanistik, maka intervensi sosialnya lebih mengarah pada diskursus komunitas. Pembahasan masing-masing diskursus menjadi semakin jelas karena memaparkan beberapa variabel yang disampaikan oleh Ife, yakni hakekat dari kesejahteraan, penerima usaha kesejahteraan sosial, peran pekerja sosial, pertanggungan jawab, dan kebijakan. Sehingga gambaran kekhasan masing-masing diskursus tersebut ada dalam skema berikut ini: 


\section{Gambar 1 \\ Empat Diskursus dalam Pengembangan Usaha Kesejahteraan Sosial}

(Adi, 2002 : 58-59)

Top Down

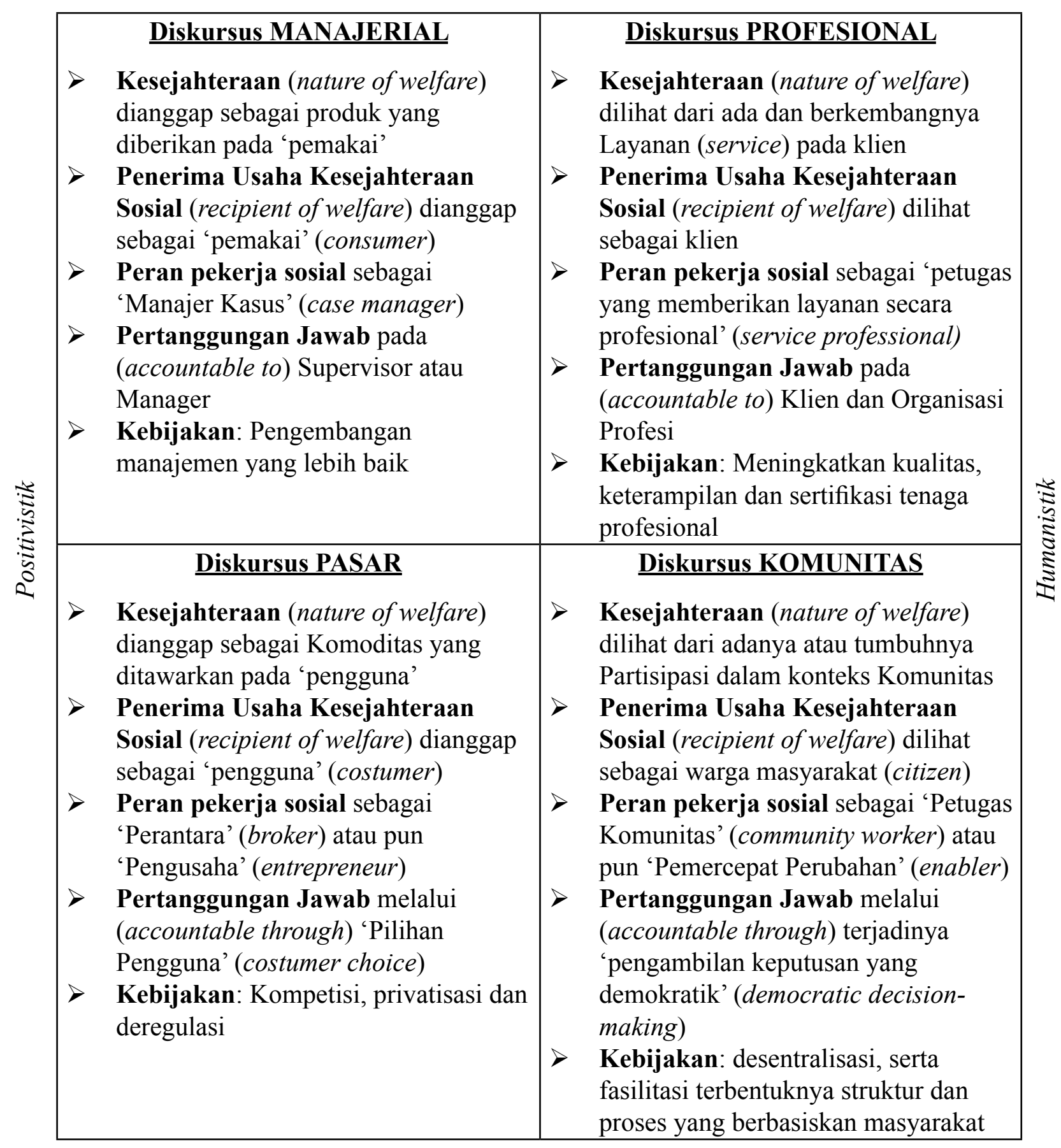

Bottom Up 
Berdasarkan keempat diskursus dalam skema 1, pemikiran yang menekankan pada urgensi manajemen LAZ dalam menentukan keberhasilan upaya intervensi sosial ternyata lebih cenderung pada diskursus manajerial. Hal ini berarti usaha kesejahteraan sosial yang digulirkan akan lebih cenderung berkiblat pada kutub top down-positivistik. Kecenderungan tersebut tentu jauh dari definisi dasar pemberdayaan ekonomi di masyarakat yang tentunya lebih mengarah pada kutub bottom up-humanistik. Dimana masyarakat sebagai subjek pembangunan memang diakui secara nyata keberadaannya.

Suatu usaha kesejahteraan sosial yang mempergunakan diskursus komunitas juga bukan berarti terlepas dari pemikiran dari urgensi manajemen dalam pelaksanaannya. Usaha kesejahteraan sosial dan LAZ dengan manajemen yang ada di dalamnya merupakan satu kesatuan di dalam sebuah sistem yang tidak dapat dipisahkan. Proses pemberdayaan ekonomi yang bersifat bottom up-humanistik pun tidak bisa diciptakan begitu saja tanpa dukungan atmosfer dari manajemen organisasi LAZ yang bersangkutan. Butcher (2004 : 57-72) menyebutkan organisasi nirlaba yang melakukan pemberdayaan ekonomi di masyarakat membutuhkan elemen berikut ini: budaya organisasi, sistem organisasi, peran-peran manajemen, dan standar prosedur operasional. Keempat elemen tersebut tidak bisa dipisahkan satu sama lain dan terkemas dalam sebuah model yang bernama "Sistem Model".

Budaya organisasi merupakan suatu cara yang diterapkan oleh suatu organisasi dalam menjalankan atau filosofi, gaya atau semangatnya (Blunt, dalam Jones, 1995 : 230). Sedangkan sistem organisasi merupakan arahan yang strategis, koordinasi dan kontrol, pemeliharaan kualitas dan pengembangan staf serta organisasi. Kemudian Standar prosedur operasional adalah berbagai hal yang terkait dengan berbagai sumber daya pendukung yang mampu mendorong kinerja sumber daya manusia. Sedangkan elemen terakhir yang berupa "peran-peran" (management roles) merupakan elemen organisasi yang menjalankan 3 kategori: hubungan interpersonal, pemberi informasi, dan pengambilan keputusan (Butcher, 2004 : 72-80).

Apabila dikaitkan dengan kegiatan LAZ yang mengedepankan proses pemberdayaan dalam intervensi sosialnya, "peran-peran manajemen" adalah elemen organisasi yang menarik untuk dikaji. Hal ini karena berawal dari sebuah asumsi bahwa atmosfer kebijakan yang bisa memfasilitasi adanya proses dan struktur yang berbasiskan masyarakat bisa berawal dari elemen ini. Terutama pada sub-elemen pengambilan keputusan yang bisa memberikan peluang kepada setiap stakeholder untuk mengambil peran. Jadi jika LAZ berkomitmen untuk menerapkan diskursus komunitas dalam setiap kegiatan usaha kesejahteraan sosial, perlu menumbuhkan organisasi dengan warna sebagaimana yang dipaparkan oleh Butcher tersebut.

Alasan selanjutnya yang membuat "management roles" menjadi suatu hal yang menarik untuk dikaji adalah karena elemen ini menjadi salah satu tahap penting dalam proses sosialisasi "budaya organisasi". Melalui elemen "management roles", kebijakan yang diterapkan oleh organisasi terkait dengan diskursus yang mendominasinya akan lebih diinternalisasikan pada tahap ini. Terutama pada saat anggota organisasi telah lama bekerja didalamnya dan konflik dari berbagai kepentingan dari individu atau kelompok bermunculan, baik secara internal maupun ekternal. Elemen "management roles" bisa meminimalisir 
berbagai kendala yang bisa membuat terjadinya ketidakefektifan sebuah proses pencapaian tujuan organisasi (Gibson, Ivancevich, James H. Donnelly, \& Konopaske, 2006 : 41-46).

Adapun beberapa kategori dari "management roles" tersebut antara lain: Kelompok peran "interpersonal”, kelompok peran "informational”, dan kelompok peran "pengambilan keputusan". Kelompok peran "interpersonal" mengarahkan proses manajerial di dalam organisasi dalam memampukan, memfasilitasi, mendukung dan memberikan saran, dari pada memerintah dan memberikan instruksi secara lansung. Sedangkan kelompok peran "informational" dalam praktek komunitas merupakan kelompok peran yang memastikan adanya komunikasi setara dan bersifat dua arah. Sedangkan kelompok peran "pengambilan keputusan" merupakan peran dimana pihak manajerial harus melakukan strategi pengambilan keputusan yang berdasarkan tantangan yang berasal dari dalam maupun luar organisasi (Butcher, 2004 : 73-79).

Terkait dengan budaya yang perlu disosialisasikan dalam organisasi yang berguna dalam pencapaian tujuan bersama, karakter organisasi pengelola zakat itu sendiri beragam. Adapun karakter LAZ sebagai salah satu OPZ itu sendiri adalah kultur kerja yang dinamis, inovatif dan kreatif. Dari empat kategori model amil zakat, LAZ termasuk dalam model organisasi bisnis, salah satu lembaga amil zakat yang masuk dalam kategori ini adalah Dompet Dhuafa (DD) (Khasanah, 2004, hal. 175). LAZ tersebut terkenal dengan komitmennya dalam mengembangkan zakat dan kebermanfaatannya. Terbukti dengan prestasinya sebagai salah satu OPZ terbaik dengan menempati peringkat ke-2 setelah BAM UI BNI. Bahkan DD juga merupakan LAZ yang bisa menggalang dana zakat terbesar ke dua setelah RZI (PEBS UI, dalam Wibisana : 213).

Selain DD, ada banyak LAZ yang bermunculan dan turut berpartisipasi dalam sejarah perzakatan modern di era 1990. Terutama pada saat beredarnya buku fiqih zakat yang dituliskan oleh Yusuf Qardhawi (Mirtanti, 2009 : v). Bahkan organisasi pelayanan yang berbentuk LAZ di Indonesia juga banyak dikembangkan oleh bank syariah turut memperkokoh perekonomian Indonesia. Salah satu bank syariah yang mengembangkan dana zakat adalah Bank Muammalat. Bank yang menjadi pionir perbankan syariah ini membangun LAZ yang bernama Baitul Maal Muammalat (BMM). Sama seperti DD, BMM juga mencoba menghimpun dana dari berbagai macam sumber. Jadi dana yang terhimpun tidak hanya berasal dari pegawai perusahaan saja. BMM juga menarik minat masyarakat dari eksternal organisasi untuk berzakat, kemudian mempercayakan BMM sebagai organisasi yang mengelola zakatnya. Trend ini pun diikuti oleh perbankan syariah lainnya yang berasal dari perbankan konvensional seperti Bank Mandiri, Bank Rakyat Indonesia, Bank Nasional Indonesia, dan lain-lain.

Namun hal yang terpenting dari keberadaan LAZ di Indonesia tentunya bukan terletak pada kuantitasnya, namun pada bagaimana LAZ memberikan pengaruh yang berkualitas dalam pembangunan di negeri ini. Pengaruh yang berkualitas tersebut artinya LAZ sebagai organisasi nirlaba (human service organization) berkemampuan melakukan usaha kesejateraan sosial yang bisa menyentuh permasalahan dan kebutuhan serta potensi masyarakat yang menjadi subjek pembangunan. Jadi pemberdayaan ekonomi yang dilakukannya memberikan kemanfaatan yang berkelanjutan (sustainable) di masyarakat 
pengguna. LAZ pun bisa memaksimalkan wacana diskursus komunitas yang berada dalam kutub bottom up-humanistik pada setiap intervensi sosialnya.

Harapan tertinggi pada proses pelaksanaan wacana diskursus komunitas juga tidak hanya terjadi di masyarakat sebagai pihak ekternal dari LAZ sebagai organisasi. Nuansa yang cenderung ke kutub bottom-up dan humanistik seyogyanya juga bisa terjadi seiring perjalanan roda organisasi, yakni pada tahap input manajemen (input), metode penyampaian layanannya (process), maupun kualitas hasil (output dan outcome). Oleh karenanya, penelitian yang bisa gambaran yang utuh mengenai bagaimana proses manajemen pendayagunaan dana zakat dan pengaruhnya terhadap kemanfaatannya di masyarakat adalah suatu hal yang menarik. Terutama apabila penelitian tersebut dilakukan dengan membandingan dua organisasi pengelola zakat yang selama ini menjadi pelopor dan memiliki kesamaan namun tetap memiliki karakteristiknya sendiri: Dompet Dhuafa-yang berlatar belakang perusahaan dan baitul maal muammalat —yang berlatar belakang perbankan.

Berdasarkan data yang diperoleh oleh BPS (2009 : 1), di Indonesia pada bulan Maret 2009 masih terdapat Jumlah penduduk miskin (penduduk yang berada di bawah Garis Kemiskinan di Indonesia pada Bulan Maret 2009 sebesar 32,53 juta (14,15 persen). 17,35 persen diantara penduduk miskin tersebut tinggal di daerah perdesaan. Kondisi ini tentu sangat memprihatinkan. Berbagai upaya pembenahan menjadi keharusan. Salah satunya adalah dengan meningkatkan potensi LAZ sebagai salah satu elemen pembangunan di negeri ini.

Zakat menjadi salah satu kapital yang sangat potensial mengingat sebagian besar warga Indonesia beragama Islam. Namun sayang karena para muzakki di Indonesia yang percayaan LAZ sebagai pengelola zakatnya baru sebagian (Suara Merdeka, 2005). Rasa percaya (trust) masyarakat yang berkewajiban membayarkan zakat terhadap LAZ di Indonesia tergantung pada performa dan hasil keluarannya (output) dari LAZ itu sendiri. Dimana keduanya tidak dapat terlepas dari manajemen organisasi.

Lembaga Amil Zakat adalah salah satu bentuk Organisasi Pengelola Zakat (OPZ) di Indonesia. OPZ itu sendiri terdiri dari berbagai macam bentuk. Ada OPZ yang merupakan lembaga pemerintahan berupa Badan Amil Zakat, Unit Pengumpul Zakat (UPZ) berbasis instansi dan perusahaan, serta amil-amil tradisional-individual berbasis masjid dan pesantren. Berbagai OPZ tersebut berkembang pesat sejak digulirkannya UU no. 38 Tahun 1999 tentang pengelolaan zakat. Sampai dengan tahun 2010, terdapat BAZNAS, 33 BAZ tingkat provinsi, $429 \mathrm{BAZ}$ tingkat Kabupaten/Kota dan 4.771 BAZ tingkat kecamatan. Sedangkan LAZ tingkat nasional berjumlah 18 dan LAZ tingkat daerah yang belum dihitung. (Rosmanita, Dewi, Wibisono, \& Lutfi, 2010 : 211-212).

Berdasarkan yang tertulis dalam dalam UU no. 38 Tahun 1999 tentang pengelolaan zakat pasal 7, LAZ sebagai salah satu bentuk organisasi pelayanan, sepenuhnya dibentuk atas prakarsa masyarakat dan oleh masyarakat. Keberadaan LAZ pun dikukuhkan, dibina dan dilindungi oleh pemerintah dan harus memenuhi persyaratan yang diatur oleh menteri. Sebagaimana dimaksud pada ayat (1), Lembaga Amil Zakat harus memenuhi persyaratan yang diatur lebih lanjut oleh Menteri. Adapun tugas dari Lembaga Amil Zakat adalah "mengumpulkan, mendistribusikan, dan mendayagunakan zakat sesuai dengan ketentuan 
agama". Pelaksanaan tugas Lembaga Amil Zakat itu sendiri bertanggung jawab kepada pemerintah sesuai dengan tingkatannya (Zakat : 2010).

Kendatipun UU Nomor 38 tahun 1999 dinilai memberikan dampak yang positif dalam perkembangan zakat di Indonesia, Wibisana (2004: 8) masih melihat adanya kekurangan dalam UU tersebut. Dalam penelitiannya, ia menyebutkan bahwa UU Nomor 38 tahun 1999 tidak mampu memberikan pengakuan legal terhadap keberadaan hukum lembaga amil zakat di Indonesia. Artinya bahwa posisi LAZ yang tidak dikenal dalam sistem hukum di Indonesia. Hal ini berimplikasi pada posisi muzakki yang sebenarnya menjadi salah satu stakeholder utama LAZ tidak memiliki perlindungan hukum. Padahal dalam UU tersebut disebutkan pula bahwa masyarakat dapat berperan serta dalam pengawasan LAZ. Namun apa yang bisa dilakukan oleh masyarakat mengenai perannya tersebut dan bagaimana LAZ memfasilitasi proses pengawasan dari masyarakat pun belum dijelaskan lebih lanjut.

Pada tahun 2011, UU Nomor 38 tahun 1999 tentang Pengelolaan Zakat diganti menjadi UU Nomor 23 Zakat Infak dan sedekah. Perubahan UU pengelolaan zakat tersebut ternyata dinilai tidak memberikan solusi terhadap permasalahan zakat di Indonesia. Sebaliknya, UU yang menekankan adanya sinergi antara unsur pemerintah dan masyakrakat sipil dalam pengelolaan dana zakat ini dilihat bisa memberikan hambatan kepada muzakki dalam menunaikan kewajibannya. Hambatan tersebut berasal dari pasal 38 yang mengharuskan LAZ untuk memiliki izin dari pejabat berwenang. Pejabat yang dimaksudkan adalah BAZNAS, LAZ milik Ormas, dan lembaga amil zakat yang berafiliasi dengan BAZNAS (Arif, 2011). Juwaini (2011) merincikan beberapa permasalahan penting yang menjadi kritik untuk UU Nomor 23 Tahun 2011 tersebut, antara lain:

"Pertama, syarat izin pendirian LAZ adalah harus didirikan oleh organisasi kemasyarakatan Islam. Padahal pada kenyataannya saat ini banyak LAZ yang telah berdiri dan beroperasi namun tidak didirikan oleh ormas Islam. Kedua, tidak diatur dan dijelaskannya kedudukan dan posisi LAZ daerah, baik LAZ propinsi maupun LAZ kabupaten/kota. Ketiga, tidak diperkenankannya kelompok masyarakat atau organisasi untuk mengelola zakat, apabila kelompok masyarakat atau organisasi tersebut tidak memiliki izin sebagai LAZ" (Juwaini, 2011).

Di satu sisi, adanya Undang-undang Zakat, Infak dan Sedekah bisa memberikan sistem yang lebih baik untuk mengawasi pengelolaan dana zakat yang kerap kali disalahgunakan oleh sekelompok orang yang mengumpulkan dana zakat untuk kepentingan pribadi. Margianto (2008) pernah menuliskan adanya upaya oknum yang mencoba meraup keuntungan dengan mempergunakan zakat sebagai kedok di Samarinda. Berita ini tentu perlu dijadikan pertanda bahwa Indonesia memang membutuhkan peraturan yang bisa meminimalisir dan bahkan menghilangkan perbuatan tercela seperti itu.

Khasanah (2004 : 175) juga telah melakukan penelitian mengenai model-model OPZ. Dalam penelitiannya,OPZ di Indonesia ada empat model yang terdiri dari:

1. Model Birokrasi

Model ini adalah organisasi pengelola zakat yang pengurusnya berasal dari unsur pemerintahan. 
2. Model Organisasi Bisnis

Model ini adalah Organisasi Pengelola Zakat yang dianut oleh Lembaga Amil Zakat, yang diprakarsai oleh karyawan di suatu perusahaan. Kultur kerjanya lebih dinamis, inovatif dan kreatif.

3. Model Ormas

Model organisasi masyarakat memiliki kultur dibawah organisasi masyarakat. Mereka memiliki semangat kerja keras namun memiliki kelonggaran yang terikat oleh disiplin kerja

4. Model Tradisional

Model amil tradisional adalah lembaga amil yang paling tua dan menjadi cikal bakal amil modern.

Dari keempat model tersebut, LAZ termasuk dalam model organisasi bisnis. Khasanah (2004 : 175) mencontohkan salah satu LAZ yang termasuk dalam model tersebut, yakni adalah Dompet Dhuafa (DD). DD diprakarsai oleh karyawan di Harian Republika. Tetapi selain DD, ada pula LAZ lain yang didirikan dari sekelompok orang yang tidak bekerja di sebuah perusahaan, misalnya PKPU (Pos Keadilan Peduli Ummat).

Berbagai terobosan untuk memperbaiki kinerja LAZ sebagai salah satu OPZ juga telah ada. Salah satunya adalah dengan menyelenggarakan "Zakat Award" (untuk BAZ) dan "Islamic Social Responsibility (ISR) Award" (untuk LAZ maupun BAZ) sebagai penghargaan kepada OPZ yang memiliki kinerja terbaik (Wibisono, 2009, h : 152-153). PEBS FEUI juga telah mengembangkan beberapa indikator yang menjadi tolak ukur penilaian kinerja OPZ dengan nama "Penilaian Kinerja Prima OPZ". Aspek utama yang ada di dalamnya adalah: Kinerja kepatuhan syariah, kinerja legalitas dan kelembagaan; kinerja keuangan dan legitimasi sosial; kinerja ekonomi; dan kinerja sosial-politik. Aspek yang pertama berhubungan dengan penerapan tata kelola yang baik. Sedangkan aspek yang kedua dan ketiga berkaitan dengan efisiensi keuangan dan efektivitas program. Kemudian aspek yang keempat menilai perihal kegiatan sosialisasi dan edukasi zakat dan penguatan kelembagaan serta jaringan kerja OPZ. Upaya PEBS-FEUI ini menunjukkan perkembangan manajemen LAZ yang begitu pesat. Apalagi bila melihat hasil penelitiannya terhadap 10 OPZ di Indonesia. Angka-angka skor yang tertera di setiap OPZ mengagumkan (Wibisono, 2009 : 45-46).

Dari berbagai aspek Penilaian Kinerja Prima OPZ ada satu indikator penting yang terkait dengan ilmu kesejahteraan sosial, yaitu efektivitas program. Mintarti, Kurniadi, \& Utomo 2009 : 19-25) pun telah melakukan perumusan performance indicator bagi program pemberdayaan masyarakat berbasis zakat. Berdasarkan penelitian yang dilakukannya, ada beberapa aspek yang bisa dipergunakan untuk mengukur outcome kualitatif pada intervensi program-program pemberdayaan masyarakat, antara lain:

a. Penguatan kelembagaan.

Indikator dari aspek ini terdiri dari pertemuan anggota (intensitas, jumlah yang hadir, follow up), organisasi kelompok (pencatatan kegiatan, pencatatan keuangan, kelengkapan pengurusan, kelengkapan struktur organisasi), kegiatankegiatan yang dilakukan kelompok(jenis-jenis, orientasi dan jumlah), peran-peran 
struktur kelompok dalam menjamin kemandirian kelompoknya, kepercayaan pihak luar kepada kelompok, dan manfaat kelompok bagi masyarakat disekitar lingkungannya.

b. Aspek peningkatan kapasitas.

Indikator aspek ini terdiri dari pemahaman kelompok (terhadap visi, tujuan dan maksud), peningkatan keterampilan (jenis-jenis, implementasi, manfaat dalam usaha), peningkatan attitude (harapan, perspektif dan sikap), dan kemampuan yang dimiliki sudah diterapkan dalam pengembangan ekonomi (kreativitas individu, semangat/optimistik, perorangan atau kelompok).

c. Aspek kewirausahaan.

Indikator aspek ini terdiri dari pengembangan modal kelompok, jenis-jenis dan karakteristik usaha yang dikembangkan, skala dan pendapatan usaha yang dikembangkan, alokasi pendapatan usaha yang dikembangkan, dan pengelolaan usaha yang dilakukan (perorangan-kelompok)

d. Kemampuan pengembangan jaringan.

Indikator aspek ini terdiri dari jumlah jaringan kerja, tingkat hubungan jejaring, dan pola kemitraan yang dikembangkan.

Penjabaran indikator performa yang dikembangkan tersebut memperjelas ketidaksederhanaan dari beban kerja yang perlu dilakukan oleh LAZ sebagai organisasi nirlaba. LAZ pun membutuhkan sebuah budaya untuk mendukung organisasi dalam mencapai tujuannya yang kompleks. Sebagaimana yang disampaikan Jones (1995 : 258), budaya organisasi itu sendiri memang akan memberikan dampak kepada pelayanan kepada konsumer.

\section{Penutup}

Berbagai literatur telah menyebutkan bahwa LAZ sebagai FBO memang memiliki potensi untuk memberikan perubahan yang bermakna dalam proses pembangunan ini. Potensi ini datang tidak salah satunya karena LAZ memiliki karakteristik yang unik sebagai Human Service Organization dan juga FBO. Sebagai sebuah Human Service Organization dan juga FBO, LAZ memungkinkan untuk melakukan berbagai pengembangan yang bisa memudahkan dirinya memberikan pelayanan yang terbaik pada penerima layanan. 


\section{Bibliografi}

\section{Buku}

Adi, I. R. Intervensi Komunitas: Pengembangan Masyarakat Sebagai Upaya Pemberdayaan Masyarakat. Jakarta: PT Rajagrafindo Utama, 2008.

Adi, I. R. Pemikiran-pemikiran dalam Pembangunan Kesejahteraan Sosial. Depok: Fakultas Ekonomi Universitas Indonesia, 2002.

Banks, S., Butcher, H., Henderson,P., dan Robertson, J. Managing Community Service (Principles, Policies, and Programmes). Bristol: MPG Books, 2004.

Beik, I. S . Analisis Peran Zakat dalam Mengurangi Kemiskinan: Studi Kasus Dompet Dhuafa Republika. Zakat dan Empowering, 2009.

Bryman, A. Social Research Methods. Hongkong: Oxford University Press, 2008.

Gilbert, N. Researching Social Life. New Delhi: Sage Publication Inc, 2008.

John, A. dan May, J. Working In Human Service Organization. Melbourne: Australia, 1995.

Krueger, R.A. Focus Group Discussion: A Practical Guide for Applied Research. London: Sage Publication, 1988.

Minichiello, V., Aroni, R., Timewell, E., \& Alexander, L. (2 ${ }^{\text {nd }}$ Eds). Indepth Interviewing. Melbourne: Longman, 1995.

Neuman, W. L. Social Research Methods (Qualitative and Quantitative Approaches). Boston: Allyn and Bacon, 2006.

Nugroho, H. Strategi Pengentasan Kemiskinan di Indonesia dalam Negara, Pasar dan Keadilan Sosial. Yogyakarta: Pustaka Pelajar, 2000. . Menumbuhkan Ide-ide Kritis. Yogyakarta: Pustaka Pelajar, 2001.

Rubin, A. dan Babbie, E.R. Research Methods for Social Work. Belmont: Thomson Brooks/ Cole, 2005.

Saidi, Z. \& Abidin, H. Menjadi Bangsa Pemurah. Jakarta: Piramedia, 2004.

Topatimasang, R. dan Dilts, R. Manajemen Organisasi Nirlaba. Jakarta: P3M, 1988.

Yusuf Wibisono, d. Menggagas Arsitektur Zakat Indonesia: Menuju Sinergi Pemerintah dan Masyarakat Sipil Dalam Pegelolaan Zakat Nasional. Jakarta: Indonesia Magnificence of Zakat, 2009.

\section{Jurnal Ilmiah}

Badan Pusat Statistik. Profil Kemiskinan di Indonesia Maret 2009. Berita Resmi Statistik, Diakses pada tanggal 30 Oktober 2009, dari http://www.bps.go.id/brs_file/ kemiskinan-01jul09.pdf, 2009 : 43(07), 1-9..

Krefting, L. Rigor in Qualitative Research. 45 (3), 1990 : 214-222.

Tangenberg, K.M. (2005). Faith-Based Human Services Initiatives: Considerations for Social Work Practice and Theory. Social Work, Diakses pada tanggal 24 Oktober 2009, dari Academic Research Library. (Document ID: 880263651). 2005: 50(3), 197-206.

\section{Artikel}

Jenis Zakat. PKPU Online. Diakses pada tanggal 30 Oktober 2009 dari http://www.pkpu. or.id/panduan.php?id=3 
Republika News Room. Menimbang Sentralisasi Zakat. Diakses pada tanggal 29 Oktober 2009 dari http://syiar.republika .co.id/36554/Menimbang_Sentralisasi_Zakat, 11 Maret 2009.

Zakat Diwujudkan dalam Program Bersifat Kail. Diakses pada tanggal 29 Oktober 2009 dari http://www.suara merdeka.com/harian/0510/29/nas17.htm., 29 Oktober 2005.

\section{Dokumen}

Departemen Agama Republik Indonesia. (tt). Undang-undang Republik Indonesia Nomor 38 Tahun 1999 tentang pengelolaan Zakat. Diakses dari www.depag.go.id/file/ dokumen/UU3899.pdf.

\section{Penelitian}

Dewi, T. Proses Penyiapan Koperasi Pada Komunitas Sasaran Program Pemberdayaan Masyarakat (Studi Kasus pada Komunitas Sasaran Program Pemberdayaan Masyarakat Lembaga Masyarakat Mandiri Dompet Dhuafa Republika di Desa Muara dan Desa Rancalabuh, Tanggerang). Depok: Program Sarjana Ilmu Kesejahteraan Sosial FISIP UI, 2006.

Fatahillah. Strategi Kebijakan Pengelolaan Zakat Di BAZIS DKI Jakarta Dalam UU Zakat No. 38 Tahun 1999 (Analsis Metode AHP). Depok: Magister Perencanaan dan Kebijakan Publik Fakultas Ekonomi Universitas Indonesia, 2003.

Fuaida, L. D. Manajemen Keuangan Keluarga Miskin: Studi Kasus Mitra Program Masyarakat Mandiri, Dompet Dhuafa Republika. Depok: Program Pascasarjana Ilmu Kesejahteraan Sosial FISIP UI, 2005.

Jaelani, A. Pengaruh Kualitas Pelayanan dan Social Marketing terhadap Keputusan Muzakki dalam berzakat. Depok: Program Pascasarjana, 2008.

Khasanah, U. Analisis Model Penanganan Zakat di Indonesia (Kajian Terhadap Badan Amil Zakat dan Lembaga Amil Zakat) . 2004: Ekonomi dan Keuangan Syariah, Program Studi Kajian Timur Tengan dan Islam, Program Pascasarjana Universitas Indonesia, 2004.

Khatimah, H. Pengaruh Zakat Produktif Terhadap Ekonomi Para Mustahiq: Studi Kasus di Community Development Circle (CDC) Dompet Dhuafa. Depok: Eonomi dan Keuangan Syariah, Program Studi Kajian Timur Tengah Islam, UI, 2004.

Sirmu. Zakat dan Pajak Dalam Hukum Islam. Depok: Program Pascasarjana Fakultas Hukum, 2007

Subekti, S. A. Aktivitas Berzakat dan Model Pengelolaan Zakat (Penelitian Terhadap Kecenderungan Pembayar Zakat di Kelurahan Tebet Barat Kecamatan Tebet Jakarta Selatan). Depok: Program Pascasarjana Kekhususan Manajemen Pembangunan Sosial Program Studi Sosiologi, 2003

Takidah, E. Analisis Pengaruh Kualitas Jasa Badan Amil Zakat Nasional Pada Kepuasan dan Kepercayaan Muzakki. Depok: Ekonomi dan Keuangan Syariah, Program Studi Kajian Timur Tengan dan Islam, Program Pascasarjana Universitas Indonesia, 2004.

Tasniawan, D. W. Administrasi Zakat menurut Undang-undang No.38 tahun 1999 terhadap Tingkat Ketertiban Wajib Zakat. Depok: Program Pascasarjana, 2008. 
Wibisana, A. Penerapan Prinsip-prinsip 'Good Corporate Governance' Pada Lembaga Amil Zakat di Indonesia (Studi Kasus pada 5 Lembaga Amil Zakat Terbesar di Indonesia). Jakarta: Fakultas Hukum Universitas Indonesia, 2004.

Yarmanto, H. Analisis Zakat Sebagai Faktor Pengurang Penghasilan Kena Pajak (Tinjauan Aspek Sinergi Antara Zakat dan Pajak). Jakarta: Kekhususan administrasi dan kebijakan Perpajakan Program Studi Ilmu Administrasi, 2003. 